\title{
Editorial
}

\section{El lenguaje de la guerra o la perpetuación de un conflicto}

El lenguaje de la guerra no es neutral. Tampoco su perpetuación. Al usar las palabras, cada agente parece darse cuenta de que, aunque las realidades le desbordan, el repertorio de retóricas les sirve a sus objetivos. Carl von Clausewitz alegaba este principio de doble oposición: "la guerra es la política por otros medios" [1]. De modo que, si el lenguaje de la guerra expresa la democracia, en Colombia el análisis de la política refleja una guerra en ciclos duraderos. ¿Qué contenidos tiene la guerra en el lenguaje político? ¿Expresa la política contenidos de la guerra? Estas son preguntas que interesan a los investigadores.

En el eje de la democracia, la guerra evoluciona: ¿podemos acaso imaginar un régimen donde se haga más evidente que en Colombia? En la mayoría de las democracias, la guerra se construye políticamente sobre posiciones de izquierda y de derecha. Con todo y sus orígenes arbitrarios (Francia, 1789, representantes entre bandos políticos), Alexis de Tocqueville describía su inestabilidad y sus expresiones conflictivas. Es difícil imaginar la política fuera de este esquema original, pero, en Colombia, es difícil interpretar los acontecimientos políticos así, sin más [2].

Desde el discurso, los analistas abordan el tema de dos maneras: una es ideológica, y abarca tanto las preferencias económicas en la redistribución de la riqueza, como las sensibilidades más generales en cuanto a la dirección y la velocidad del cambio. Simplificando, la derecha se basa en la creación de riqueza y en reservas hacia el cambio social ("conservadurismo"), mientras la izquierda recompensa la redistribución de la riqueza existente y la experimentación social ("progresismo"). La segunda forma de percibir esta transmutación de la guerra en política es territorial. En Colombia, los territorios de la guerra se encuentran en regiones olvidadas, o con ausencia parcial del Estado. Y la política no es más que una expresión condicionada, bien por el representante heredero de familia, clan o elite, o bien por mecanismos de extorsión violenta de agrupaciones dominantes.

Como es obvio, estas retóricas no siempre son compatibles. Ambas, sin embargo, defienden la lógica de guerra entre dos extremos (el uso de términos eufemísticos, metáforas, es revelador). Paradójicamente, un enfoque más macroscópico muestra que la guerra, en Colombia, parece servir a una síntesis más amplia. Desde esta perspectiva, por ejemplo, es imposible imaginar el proceso electoral colombiano más allá de la síntesis de derecha e izquierda. Sin el discurso de izquierda, los Gobiernos se conducen a una polarización social extrema y al estancamiento; y sin el discurso de derecha, somos vulnerables a la pobreza, la nivelación social.

Al adoptar posiciones de "centro", "centro izquierda", "centro derecha" y, en general, el "centro" como la equidistancia que regula la realidad política, esto haría sabias las alternancias, mitigaría los extremos, supone una suerte de mano invisible en la política. Obviamente, las retóricas de la intransigencia siguen gravitando en el lenguaje político; de nuevo, es la misma evolución del modelo de sociedad, del sistema democrático que hemos construido. La democracia, en su expresión electoral, refleja un conflicto político, que a su vez traslada la guerra a la esfera del discurso, de la retórica, de las palabras.

Del mismo modo, estas recomposiciones retóricas reflejan a menudo tendencias globales, así como se observa la gran propensión a la redistribución que siguió a la Constitución de 1991 y los correctivos a las políticas neoliberales con Gobiernos anteriores, políticas del Consenso de Washington, Ronald Reagan y Margaret Thatcher. Es posible que nos encontremos ante un punto de inflexión histórico semejante. Quizás una tendencia a la redistribución corrija la enorme acumulación de riqueza provocada por la globalización.

En Colombia - es importante subrayarlo_- sin embargo, no todas las regiones, territorios, departamentos, se encuentran en la misma posición del ciclo global. Y esto es de especial atención para la forma como interpretamos los conflictos y su duración. El lenguaje de la guerra, como la política, adquiere características de lugar. ¿Determina acaso el ciclo global la "guerra contra las drogas"? Si la respuesta es no, se sigue esta otra pregunta: ¿no son acaso temas de seguridad los que decidirán la política electoral en Colombia?

De hecho, no siempre las retóricas en la política han estado acompasadas en el contexto internacional. Colombia es un ejemplo. Durante la década de los ochenta del siglo xx, el auge de la guerra contra el narcotráfico coincidía con la apertura comercial; el discurso sobre la redistribución de la riqueza fue entonces subordinado. Hoy, en el debate 
político y tras las marchas y los paros sociales sucesivos, el imperativo de la redistribución está de regreso. El discurso político se encuentra atrapado.

Mientras políticamente la guerra de palabras (centro-derecha-izquierda) es tema de diálogo en las ciudades capitales, en las regiones que concentran el conflicto, las desigualdades económicas tienden a perpetuar una mayor pobreza. En cincuenta años (1970-2020), Colombia lograba salir de un largo tiempo de atraso. Salía del subdesarrollo. Al mismo tiempo, entraba en una guerra que combinaba todas las formas de lucha: narcotráfico, autodefensas, insurgencia, bandas criminales. Los desafíos en Colombia pasan por determinar qué tanta inclinación tenemos hacia los cambios globales por una mejor redistribución de las riquezas, o hacia la prolongación de la guerra en sus diversas manifestaciones. Clausewitz usa la analogía de la guerra como el camaleón: al cambiar sus formas, se adapta a nuevas circunstancias. Con la guerra, el lenguaje cambia, y viceversa.

En este contexto, las palabras se relacionan con acciones. Los discursos son actos de habla. La evolución de la violencia pública contiene una amplia gama de aprendizajes. Y los cambios políticos trasladan a la realidad las creencias, afirmaciones y retóricas de los distintos actores.

Agreguemos que la guerra posterior a los acuerdos con las Fuerzas Armadas Revolucionarias - Ejército del Pueblo se encuentra en sus peores momentos. La amenaza no viene propiamente de un "para-Estado", como se juzgaba bajo el régimen de Gobiernos permisivos de una especie de "parapoder". Un país de contrastes. Las recientes acciones insurgentes, el poder territorial ejercido actores de la guerra, parece contradecir el restablecimiento de los canales democráticos y la relativa estabilidad institucional conseguida. Esto anterior aplica en zonas del Pacífico o del Caribe.

Aunque estos años de transición han mejorado las condiciones del país, se siguen manteniendo estructuralmente mecanismos extrainstitucionales que socavan los poderes del Estado. Estos mecanismos comparten ciertas características comunes, en particular, el uso de la violencia como medio de intervención política. Líderes comunitarios asesinados y exintegrantes de las guerrillas, mujeres y adolescentes forzados a integrar las nuevas agrupaciones constituyen acciones en una violencia de baja intensidad. Los nombres cambian, las palabras cambian, pero las acciones replican viejas modalidades de poder en determinadas localidades.

En el epicentro de estos fenómenos encontramos las prácticas de violencia pública. Durante los Gobiernos de Juan Manuel Santos e Iván Duque, la adopción de medidas para contrarrestar el accionar de estas agrupaciones ha sido ineficiente. Las pocas tropas profesionales que antes cubrían estas áreas han sido replegadas. La presencia del "Clan del Golfo", "Los Caparros" y otras organizaciones al servicio del crimen recrudece las manifestaciones de la guerra.

De manera semejante a sus versiones anteriores, agentes paraestatales logran mantenerse en estas regiones, debido a que gozan de inmunidad en un espacio político más amplio. En departamentos como Cauca, Nariño, Norte de Santander, ejercen cobertura mediante la economía del narcotráfico. Las capturas de mandos medios o exparamilitares en ejercicio no enseñan nada nuevo. Simplemente, repiten un patrón reconocido: más violencia (ataques a la población, ataques a puestos militares, desplazamiento forzado), con lo que la amenaza de perpetuar la guerra sigue vigente.

El lenguaje de la guerra y el conflicto van unidos. Los nombres cambian, el enemigo público no. Estos años han servido para procesar un largo aprendizaje. El paramilitarismo de nuevas versiones ha replicado, además, efectos contradictorios, fortaleciendo a sus enemigos. Así que los Gobiernos tienen como tarea evitar el sometimiento de estas regiones a la anarquía; pero más importante, a que la presencia del Estado no sea confundida con un tipo de poder aliado con los violentos. Analizar el lenguaje de la guerra en Colombia es, entonces, atender a la dinámica de cambios que pueden tener más de apariencia que de realidad.

Fernando Estrada

Profesor e investigador de la Universidad Industrial de Santander

DOI: https://doi.org/10.17533/udea.rfnsp.e347711

\section{Referencias}

1 Clausewitz KV. De la Guerra. Madrid: Tecnos; 2010.

2 Tocqueville A. Recuerdos de la Revolución de 1848. Madrid: Editorial Trotta

Esta obra se distribuye bajo una Licencia Creative Commons Atribución-NoComercial-CompartirIgual 4.0 Internacional Más información: https://creativecommons.org/licenses/by-nc-sa/4.0/ 